\title{
Kajian Pustaka: Kadar Brain Derived Neurotrophic Factor Mempengaruhi Berat Badan Lahir pada Bayi
}

\author{
Yessi Ardiani ${ }^{1}$, Defrin $^{2}$, Husna Yetti ${ }^{3}$ \\ Pendidikan IImu Kebidanan Pascasarjana Fakultas Kedokteran Universitas Andalas ${ }^{1}$ \\ Bagian Obstetri dan Gynecologi Fakultas Kedokteran Universitas Andalas ${ }^{2}$ \\ Bagian Ilmu Kesehatan Masyarakat Fakultas Kedokteran Universitas Andalas ${ }^{3}$ \\ e-mail: yessiardiani@gmail.com
}

\begin{abstract}
Brain Derived Neurotrhophic Factor (BDNF) is one of the proteins needed for the growth of neurons. During its development period BDNF plays a role in nerve growth, differentiation, repair, and survival of nerve cells. In addition, researchers from certain groups found that BDNF also had an important role during the implantation period, placental development and development of fetal growth. BDNF is known to have an important role in regulating angiogenesis needed for placental development. Because of this role, BDNF deficiency will cause disruption in placental growth which will eventually cause fetal growth disorders or Intrauterine growth restriction (IUGR). In recent years studies have shown that neurotrophins play an important role in the regulation of placental development and fetal growth. BDNF has been found to be expressed in large amounts in blastocysts which indicate the potential role of BDNF in implantation and development of the placenta. BDNF is also produced in the muscle tissue of one of them in the uterus precisely in the endometrium and myometrium. The discovery of the role of $B D N F$, is expected to be used as an indicator to assess the occurrence of growth disorders in the fetus as well as additional information about the etiology and pathophysiology of IUGR.
\end{abstract}

Keywords:

BDNF; IUGR; Neurotrophin

\section{PENDAHULUAN}

BDNF merupakan salah satu hormon yang termasuk dalam keluarga neurotrofin. Hormon lain yang termasuk dalam kelas neurotrofin yang ada pada mamalia adalah Nerve Growth Factor (NGF), Neurotrophin-3 (NT-3) dan Neurotrophin-4/5 (NT-4/5) (Ganong, 2008). Umumnya kelas neurotrofin penting dalam pertumbuhan neuron atau neurogenesis, tapi baru-baru ini telah ditemukan peran neurotrofin yang signifikan dalam proses implantasi, perkembangan plasenta dan pertumbuhan janin pada kehamilan (Mayeur et al., 2010).

Semua anggota neurotrofin merupakan peptida dengan ukuran kecil (Nestler, Hyman, dan Malenka, 2009). BDNF dibentuk dari molekul prekursor pro-BDNF. Sebuah BDNF yang matang memiliki berat peptida $14,5 \mathrm{kDa}$ yang dihasilkan dari $32 \mathrm{kDa}$ pro-BDNF. Dalam beberapa penelitian ditemukan bahwa pembelahan yang mengarah ke pembentukan BDNF matur diatur oleh enzim dari golongan proprotein convertase (PCs) seperti furin atau PCl (Preedy, Watson dan Martin, 2011).

\section{Reseptor Neutrofin}

Neurotrofin bekerja pada dua kelas reseptor yang sama sekali berbeda. Reseptor pertama yang ditemukan dinamakan p75 neurotrophin receptor (p75NTR). Reseptor p75 merupakan protein seberat $75 \mathrm{kDa}$ yang merupakan reseptor neurotrofin dengan afinitas yang rendah. Reseptor p75 mengikat semua anggota neurotrofin dengan afinitas yang secara kasar hampir sama. Reseptor p75 justru memiliki afinitas yang tinggi jika berikatan dengan prekursor neurotrofin (proneurotrophin) (Lihat Gambar 1). Reseptor p75 juga mengatur sinyal Trk (tropomyosin related kinase) -reseptor neurotrofin yang lain- dengan membuat reseptor Trk bereaksi terhadap NGF konsentrasi rendah. Sebagai tambahan, p75 juga membuat TrkA dan TrkB lebih selektif dalam ikatan utamanya dengan NGF dan BDNF. Namun demikian, reseptor Trk juga dapat berfungsi sempurna dalam mengikat neurotrofin di saat tidak adanya p75 (Nestler, Hyman dan Malenka, 2009).

Selain reseptor p75, reseptor utama yang lain adalah Trk (tropomyosin related kinase). Reseptor Trk mempunyai afinitas yang kuat dengan empat kelas neurotrofin. Terdapat 3 tipe TrK yaitu TrK A, TrK B dan TrK C. Berlawanan dengan p75 yang dapat mengikat semua kelas neurotofin, tiap reseptor TrK berikatan dengan neurotrofin yang spesifik. BDNF berikatan dengan Trk B bersama dengan NT-4 (Gambar 1) (Nestler et al., 2009).

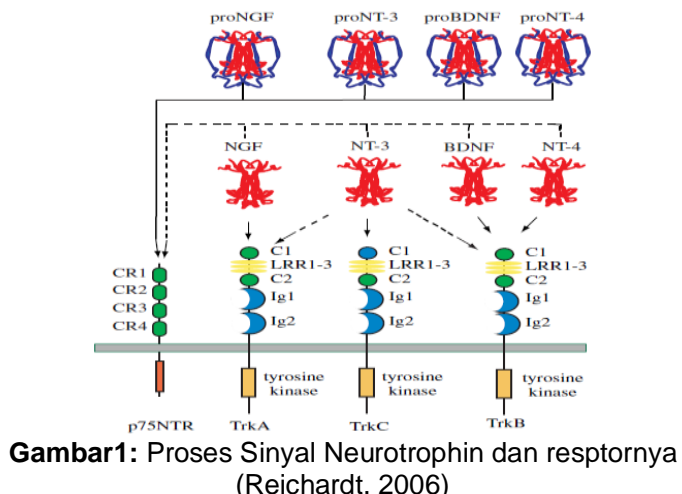

(Reichardt, 2006) 
Kebanyakan efek biologi BDNF diperantarai melalui reseptor TrkB. BDNF yang berikatan dengan TrkB merangsang reseptor dimerisasi, fosforilasi, dan aktivasidari domain tirosin kinase intraseluler. Terdapat 3 sub jenis dari reseptor TrkB. TrkB yang memiliki panjang sempurna dinamakan TrkB-FL (TrkB FullLength) dan dua TrkB dengan panjang tidak sempurna (cacat / buntung) yaitu TrkB.T1 dan TrkB.T2 yang dihasilkan oleh penjalinan alternatif dari mRNA TrkB yang digambarkan pada mamalia. Walaupun kekurangan aktivitas tirosin kinase intraseluler, TrkB.T1 dan TrkB.T2 juga aktif secara biologi karena keduanya dapat memicu sinyal transduksi yang memerlukan kehadiran sekuensing spesifik-isoform pendek intraseluler (Lihat Gambar 2 dan 3) (Preedy et al., 2011).

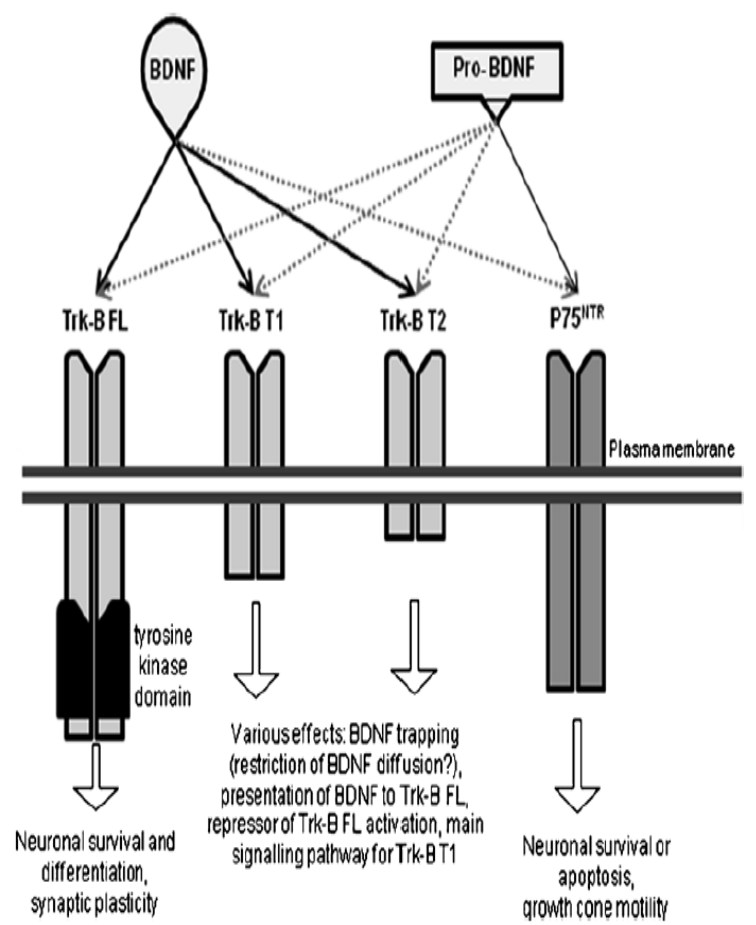

Gambar 2 : Interaksi Pro BDNF dan BDNF beserta reseptornya. (Preedy, Watson \& Martin, 2011)

Reseptor p75 mengatur 3 jalur sinyal utama. Salah satunya yaitu melalui NF-KB yang seperti telah dijelaskan merupakan jalur untuk dapat mempertahankan sel. Jalur lainnya yaitu melalui RhoA dan Jun Kinase yang keduanya dapat menyebabkan kematian sel neuron. Reseptor TrK juga mempunyai 3 jalur sinyal yang utama. Aktivasi Ras akan menyebabkan aktifnya jalur MAP kinase yang menyebabkan diferensiasi neuron termasuk pertumbuhan neurit. Aktivasi P13 Kinase melalui Ras atau Gab 1 akanmenyebabkan pertahanan neuron dan pertumbuhan neuron. Aktivasi PLC-y1 menyebabkan aktifnya $\mathrm{Ca}^{2+}$ dan mengaktifkan jalur protein kinase C-regulated yang menyebabkan plastisitas sinaps (Reichardt, 2006).

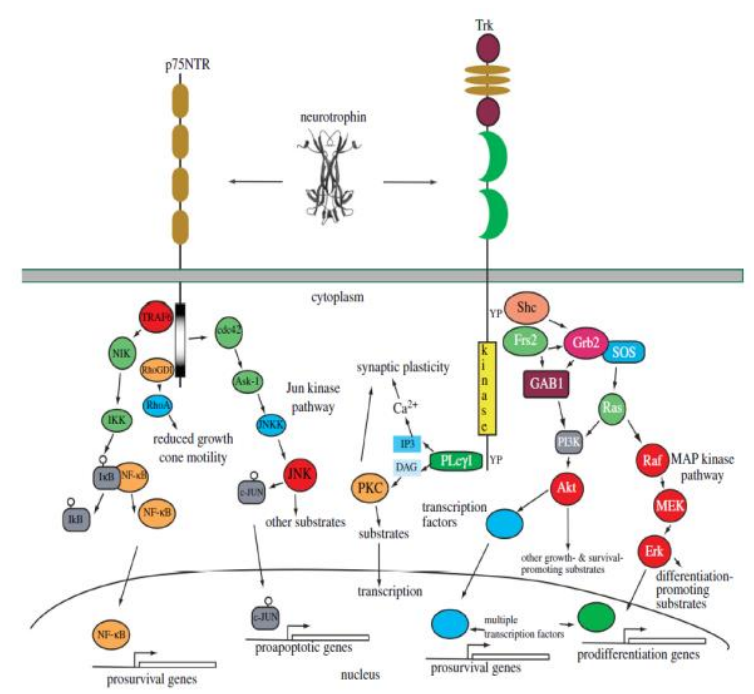

Gambar 3 : Proses Sinyal Neurotrophin (Reichardt, 2006)

\section{BDNF dan Reseptornya}

BDNF dan reseptornya secara luas didistribusikan melalui otak, jantung, limpa, kelenjar submandibular, kulit, jaringan paru. BDNF juga ditemukan pada kadar yang dapat diukur pada platelet darah dan plasma sirkulasi. BDNF juga diekspresikan pada air ludah manusia (Mandel, Ozdener dan Utermohlen, 2011). Selain itu, BDNF dan reseptornya juga ternyata ditemukan pada sejumlah jaringan reproduksi termasuk ovarium dan plasenta (Wessels et al., 2014).

\section{Kadar BDNF}

Kadar BDNF pada tali pusat di kehamilan normal adalah sekitar 1,357 $\pm 1,718 \mathrm{pg} / \mathrm{ml}$ (Bienertova-Vasku et al., 2013). Sejumlah penelitian yang lain juga melaporkan efek neurotrofin terhadap sel non-neuron seperti sel endotel dan sel otot polos pada berbagai organ yang berbeda (Sahay et al., 2015).

\section{BDNF Mempengaruhi Berat Lahir Pada Bayi}

Plasenta merupakan organ pusat sementara yang dirancang secara unik untuk membawa nutrisi, gas, antibodi, hormon, faktor pertumbuhan dan produk sisa antara ibu dan janin. Pada penelitian beberapa tahun terakhir menunjukkan bahwa neurotrofin berperan peran penting dalam regulasi perkembangan plasenta dan pertumbuhan janin (Sahay et al., 2015). BDNF telah ditemukan diekspresikan dalam jumlah yang banyak pada blastokis yang mengindikasikan peran potensial BDNF dalam implantasi dan perkembangan plasenta (Fujita et al., 2011). BDNF juga dihasilkan di jaringan otot salah satunya pada uterus tepatnya di endometrium dan miometrium (Russo et al., 2012; Wessels et al., 2014). Pada tingkat plasenta, sistem sinyal BDNF/TrkB 
meningkatkan pertumbuhan dan perkembangan sel trofoblas selama periode post implantasi khususnya pada daerah "labirin", area yang terdiri dari labirin trofoblas yang didasari oleh pembuluh darah yang menyediakan permukaan yang luas untuk pertukaran nutrisi, zat sisa dan gas (Mayeur et al., 2010).

Sumber neurotrofin untuk pertumbuhan dan perkembangan plasenta dan janin didapat dari ibu atau dapat juga diekspresikan di plasenta. BDNF telah dibuktikan dapat tembus melewati sawar plasenta (Sahay, Sundrani dan Joshi, 2017). Peningkatan BDNF ditunjukkan pada pemeriksaan darah tali pusat seiring dengan bertambahnya usia kehamilan. Hal ini menunjukkan bahwa BDNF memainkan peran penting dalam perkembangan otak manusia selama masa kehamilan lanjut (Chouthai et al., 2003).

Nutrisi maternal juga dapat mempengaruhi status BDNF/TrkB plasenta dan ini menunjukkan bahwa BDNF/TrkB penting untuk pertumbuhan perkembangan fetoplasenta dan mungkin terlibat dalam proses patologi terjadinya kelainan pada plasenta dan pertumbuhan janin. Telah ditemukan bahwa kadar BDNF tali pusat yang berbeda pada pasien preeklampsia dibandingkan dengan kehamilan normal walaupun bagaimana tepatnya peran neurotrofin dalam mempengaruhi perkembangan plasenta dan janin pada preeklampsia sampai saat ini belumlah diketahui (Bienertova-Vasku et al., 2013).

Selama kehamilan, neurotrofin plasenta memainkan peranan penting dalam mengatur angiogenesis yang diperlukan untuk perkembangan plasenta dan mempengaruhi perkembangan organ seperti otak. Neurotrofin juga dikenal dengan istilah "angioneurins" terkait dengan efek angiogeniknya (Sahay et al., 2015). Penelitian yang dilakukan pada sel neuroblastoma didapatkan bahwa aktivasi TrkB oleh BDNF merangsang ekspresi VEGF melalui hypoxia-inducible factor-1a (Nakamura et al., 2006).

\section{Faktor yang Mempengaruhi Kadar BDNF}

Terdapat beberapa faktor yang mempengaruhi kadar BDNF, diantaranya adalah usia, jenis kelamin, berat, anemia defisiensi besi dan depresi. BDNF berbanding terbalik dengan usia dan berat. Semakin tua dan semakin berat seseorang, semakin menurun BDNFnya. Penelitan membuktikan responden pada usia 20-33 tahun memiliki BDNF lebih tinggi dibanding responden dengan usia 34 tahun ke atas. Wanita juga cenderung memiliki BDNF yang rendah dibandingkan dengan pria. Wanita hamil dengan depresi juga memiliki konsentrasi BDNF yang rendah (Fung et al., 2015) ; (Lommatzsch et al., 2005). Kadar BDNF tali pusat juga dipengaruhi oleh ferritin maternal dimana kadarnya cenderung lebih rendah pada ibu dengan anemia defisiensi besi $(<12 \mathrm{ng} / \mathrm{ml})$ dibanding ibu dengan kadar ferritin normal ( $\geq 12$ $\mathrm{ng} / \mathrm{mL}$ ) (Yusrawati et al., 2018).

Otak yang memproduksi BDNF merupakan tempat dimana konsentrasi besi paling tinggi. Besi merupakan salah satu mikronutrien penting yang dibutuhkan untuk perkembangan dan fungsi sel otak. Ketika terjadi defisiensi besi, terjadi pengurangan ekpresi BDNF pada otak yang lebih jauh akan mengakibat perubahan perilaku dan kognitif yang biasanya dapat diamati pada pasien dengan depresi (Estrada et al., 2014).

\section{SIMPULAN}

Penyebab IUGR cendrung karena gangguan mekanisme utero plasenta dari ibu ke janin. Salah satu faktor yang mempengaruhi proses pertumbuhan plasenta adalah BDNF yang berperan penting dalam angiogenesis. Penemuan tentang peranan BDNF ini, diharapkan dapat dijadikan sebagai indikator untuk menilai terjadinya gangguan pertumbuhan pada janin serta sebagai tambahan informasi mengenai etiologi serta patofisiologi IUGR.

\section{DAFTAR PUSTAKA}

Bienertova-Vasku, J., Bienert, P., Zlamal, F., Splichal, Z., Tomandl, J., Tomandlova, M. et al. (2013). Brain-derived neurotrophic factor and ciliary neurotrophic factor in maternal plasma and umbilical cord blood from pre-eclamptic and physiological pregnancies. Journal of Obstetrics and Gynaecology , 359-363.

Chouthai, NS. Sampers, J. Desai, N. \& Smith, GM. (2003). Changes in Neurotrophin Levels in Umbilical Cord Blood From Infants With Different Gestational Ages and Clinical Conditions. Pediatric Research, 53 (6).

Estrada, JA. Contreras, I. Pliego-Rivero, FB. \& Otero, GA. (2014). Molecular mechanisms of cognitive impairment in iron deficiency: Alterations in brain-derived neurotrophic factor and Insulinlike growth factor expression and function in the central nervous system. Nutritional Neuroscience

Fujita, K. Tatsumi, K. Kondoh, E. Chigusa, Y. Mogami, H. Fujii, T. et al. (2011). Differential expression and the antiapoptotic effect of human placental neurotrophins and their receptors. Placenta.

Fung, J. Gelaye, B.Qiu-Yue Z. Rondon, MB. Sanchez, SE. Barrios, YV. et al. (2015). Association of decreased serum brainderived neurotrophic factor (BDNF) concentrations in early pregnancy with antepartum depression. BMC Psychiatry. 
Ganong, WF. (2008). Buku Ajar Fisiologi Kedokteran. (Alih Bahasa : Brahm U.Pendit) Jakarta: EGC.

Lommatzsch, M. Zingler, D. Schunbaeck, K. Schloetcke, K. Zingler, C. Schuff-Werner, P. et al. (2005). The impact of age, weight and gender on BDNF levels in human platelets and plasma. Neurobiology of Aging , 115-123

Mandel, AL. Ozdener, H. \& Utermohlen, V. (2011). Brain-derived Neurotrophic Factor in Human Saliva: ELISA Optimization and Biological Correlates. J Immunoassay Immunochem , 18-30.

Mayeur, S. Silhol, M. Motrot, E. Barbaux, S. Breton, C. Gabory, A. et al. (2010). Placental BDNF/TrkB Signaling System is Modulated by Fetal Growth Disturbances in Rat and Human. Placenta.

Nakamura, K. Martin, KC. Jackson, JK. Beppu, K. Chan-Wook,W. \& Thiele, CJ. (2006). Brain-Derived Neurotrophic Factor Activation of TrkB Induces Vascular Endothelial Growth Factor Expression via Hypoxia-Inducible Factor-1A in Neuroblastoma Cells. American Association for Cancer Research .

Nestler, EJ. Hyman, SE. \& Malenka, RC. (2009). Molecular Neuropharmacology: $A$ Foundation for Clinical Neuroscience 2nd Edition. USA: McGraw-Hill.

Preedy, VR. Watson, RR. \& Martin, C. R. (2011). Handbook of Behavior, Food and Nutrition (Vol. 1). New York: Springer.

Reichardt, LF. (2006). Neurotrophin-regulated signalling pathways. Philosophical Transactions of the Royal Society B, 361, 1545-1564.

Russo, N., Russo, M., Daino, D., Freschi, L., Fiole, L., Merlini, S., Bucci, F et al. (2012). Evaluation of brain-derived neurotrophic factor in menstrual blood and its identification in human endometrium. Journal of gynecological endrocrinology, 18 (6) $492-495$.

Sahay, AS. Sundrani, DP. \& Joshi, SR. (2015). Regional Changes of Placental Vascularization in Preeclampsia: A Review. International Union of Biochemistry and Molecular Biology, 67, 619-625.

Sahay, AS. Sundrani, DP. \& Joshi, SR. (2017). Neurotrophins: Role in Plasental Growth and Development. In G. Litwack, Neurotrophins (pp. 243-260). USA: Elsevier.

Wessels, JM. Wu, L. Leyland, NA. Wang, H. \& Foster, WG. (2014). The Brain-Uterus Connection: Brain Derived Neurotrophic Factor (BDNF) and Its Receptor (Ntrk2) Are Conserved in the Mammalian Uterus. PLOS ONE.
Yusrawati; Rina, G; Indrawati, LN; Machmud R. (2018). Differences in brain-derived neurotrophic factorbetween neonates born to mothers with normal and low feritin. Asia Pac J Clin Nutr ;27(2):389-392. 